\title{
Method of Analysis of the Reasons and Consequences of Traffic Accidents in Uzbekistan Cities
}

\author{
Jamshid Abdunazarov $^{1 *}$, Kudratulla Azizov ${ }^{2}$, Ilkhomjon Shukurov $^{3}$ \\ ${ }^{1}$ Department of Ground Transport Systems, Jizzakh Polytechnic Institute, Jizzakh 130100, Uzbekistan \\ ${ }^{2}$ Department of Construction and Operation of Roads, Tashkent Institute for the Design, Construction and Operation of Roads, \\ Tashkent 100060, Uzbekistan \\ ${ }^{3}$ Department of Urban Planning, Moscow State University of Civil Engineering, Moscow 129337, Russia
}

Corresponding Author Email: jamshid@jizpi.uz

https://doi.org/10.18280/ijsse.100407

Received: 13 July 2020

Accepted: 20 August 2020

\section{Keywords:}

correlation analysis, road safety, traffic accident, traffic violations, Uzbekistan

\begin{abstract}
The article is devoted to the problems in the analysis of road safety in the cities of Uzbekistan, specifically addressing issues with the occurrence of traffic accidents and the analysis of their statistics. The purpose of the article is to study the relationship between violations of traffic rules and the occurrence of traffic accidents in Uzbekistan. This study used the statistical method of correlation analysis and revealed a linear correlation between factors such as the number of traffic violations - the number of traffic accidents; the number of traffic violations - the number of fatalities from traffic accidents; the number of traffic violations - the number injured by traffic accidents; the number of traffic violations - the number of traffic accidents with economic damage. To determine the degree of correlation between the number of violations of traffic rules, the number of road traffic accidents and their consequences, the authors used the coefficient of determination. The results of the study showed that the number of traffic violations is negatively correlated with the number and consequences of traffic accidents. The authors argue that the methodology for registering a traffic accident in Uzbekistan requires modification and that a traffic accident is affected not only by violations of the rules of the road for drivers but also by other factors, such as the design of elements of the road traffic network.
\end{abstract}

\section{INTRODUCTION}

The number of road traffic deaths continues to climb, reaching 1.35 million worldwide a year. The rates of road traffic deaths relative to the size of the world's population have stabilized in recent years, but $93 \%$ of the world's fatalities on roads occur in low- and middle-income countries, even though these countries have only approximately $60 \%$ of the world's vehicles. Road traffic accidents cost most countries $3 \%$ of their gross domestic product. More than half of all road traffic deaths are among vulnerable road users: pedestrians, cyclists, and motorcyclists. The data presented in "The Global Status Report on Road Safety 2018" of the World Health Organization show that progress has been achieved in important areas such as legislation, vehicle standards and improving access to post-crash care $[1,2]$.

The statistics show that an increasing number of traffic accidents is one of the initial problems for all countries. This is particularly true for those countries in which economies are developing progressively, called developing countries, such as Uzbekistan. The population of Uzbekistan is more than $34 \mathrm{mln}$ $[3,4]$. and the length of its road network is $184,783 \mathrm{~km}$, of which public roads represent $42,530 \mathrm{~km}$, internal local roads represent $71,324 \mathrm{~km}$, and city streets and roads represent $69,229 \mathrm{~km}$. Public roads are the main highways in this country $[5,6]$.

According to the Pulitzer Center on Crisis Reporting, Uzbekistan has the lowest rates of road mortality among the countries of the region; for every 100,000 people, there are 11.32 deaths, and losses from road accidents represent $2.8 \%$ of GDP; although this is one of the lowest indicators, according to experts, the losses from traffic accidents represent substantial amounts [7].

The study of the causes, circumstances and conditions of traffic accidents plays a critical role in the development of measures for the prevention of such accidents in road transport $[8,9]$. Any accident results not only from not observing a traffic rule but also from deviations from the optimal conditions for the driver-car-road-pedestrian-environment system.

\section{MATERIAL ANALYSIS}

Violation of the traffic rules of the road is dangerous because there is a relationship between the number of violations and the number of traffic accidents, as shown by a number of studies by foreign scientists such as Zhan et al. [10, 11], who studied the risk factors associated with traffic violations and the seriousness of accidents in China. Harrington and McBride [12] studied traffic violations by sex, type, and age in California, USA. Pesic et al. [13] studied the possibility of improving road safety based on an analysis of a database on traffic violations in Serbia. Rimmö and Åberg [14] examined the issue of traffic rule violations and Swedish drivers' errors. Azemsha et al. [15] analysed the data of traffic 
accidents and their causes in the city of Gomel. Ayuso et al. [16] studied the effect of traffic violations on the cost of accidents with victims in Spain. Yusupov [17] conducted a multivariate analysis of traffic violations by drivers of vehicles in Tajikistan. Ilyina et al. [18] analysed the accident rate and the reasons for drivers violating traffic rules in the Penza region. Elliott et al. [19] studied the issues of errors and irregularities regarding the risk of motorcyclist accidents. Mesken et al. [20] examined the issue of interpersonal impairment, speeding and their relationship with traffic accidents in Finland; Parker et al. [21] investigated driving errors, traffic violations and their participation in traffic accidents. Liu et al. [22] claim that the penalty point strategy exhibits deterrent and binding effects; however, the penalty fine strategy does not show the expected effects where can subsequently reduce traffic accidents.

\section{ANALYSIS METHOD}

We have analysed data from the official database of violations of traffic rules of the Ministry of Internal Affairs of the Republic of Uzbekistan. For the period from 2016 to 2019, approximately 17 million traffic violations were noted. It was found that not all data from the traffic violations database can be used to improve road safety.

Therefore, it is necessary to analyse and determine which data on offences are valid or relevant for further analysis and the determination of measures. Relevant data are those that can be used for analysis, to directly or indirectly draw conclusions, and to help propose appropriate measures to improve road safety.

To determine relationships or interdependencies, statistical methods such as the regression analysis of traffic accidents and other indicators of road safety (traffic accidents and their consequences) and other known methods for the analysis of road safety can be used, depending on the specific data being analysed.

The types of data regarding violations of traffic rules are highlighted as follows:

(1). Information related to the offender: name and surname, gender, date and place of birth, address, identification number, as well as other identification data that determine and accurately identify the offender.

(2). Data associated with the place of the offence: the place, road, road sections, intersection, address with house number, etc.

(3). Data relating to the time the crime was committed: the year, month, day of the week and hour at the crime was committed.

(4). Data related to the crime committed: type of crime or legal qualification of the crime and resulting punishment.

(5). Other data - identification of the offence, information about the patrol officer who registered the offence at the police station.

To more accurately determine the relationship between the number of traffic violations and the number and consequences of traffic accidents, a correlation analysis was carried out for 14 regions of Uzbekistan.

\section{RESEARCH RESULTS}

According to the General Directorate of Road Traffic Safety of the Ministry of Internal Affairs of the Republic of Uzbekistan, on average, 2.0 thousand people die every year on highways [23]. Although in the republic over the past 10 years, the average number of vehicles has increased by $58 \%$ and the population by $16 \%$, the total length of roads has increased by only 4.0 thousand $\mathrm{km}$, or $2.1 \%$.

The total number of accidents and victims in the Republic of Uzbekistan are shown in Figure 1 and Figure 2.

General statistics show that in recent years, traffic accidents and the number of injuries has been decreasing in Uzbekistan. However, experts believe that the actual situation is worse than shown by the statistics. If pay attention the number of traffic accidents in Figure 2 was the highest in 1990 and 1991, after which the number dropped sharply. This is due to the fact that in 1991 Uzbekistan became an independent country and since this year the methods of providing data on traffic accidents have changed and today this data is not available in the public domain even in Global status report on road safety of World Health Organization. And the data provided by the official authorities does not show the whole situation on the roads. When analysing road accidents by region, it can be seen that the situation has been improving over the years in Tashkent city and in the Tashkent region. However, in the Surkhandarya, Samarkand, Jizzakh, Bukhara, Namangan and Navoi regions, the number of accidents has held steady or increased (Figure 3 ). One of the reasons for the sharp decrease in traffic accidents in Tashkent is explained by the 2017 installation of photo and video recording systems at 115 intersections of the city, accompanied by a mechanism for imposing fines on drivers for violating the rules of the road. This technique is used by a number of foreign countries to prevent violation of traffic rules and, as a consequence, reduce traffic accidents [25-28].

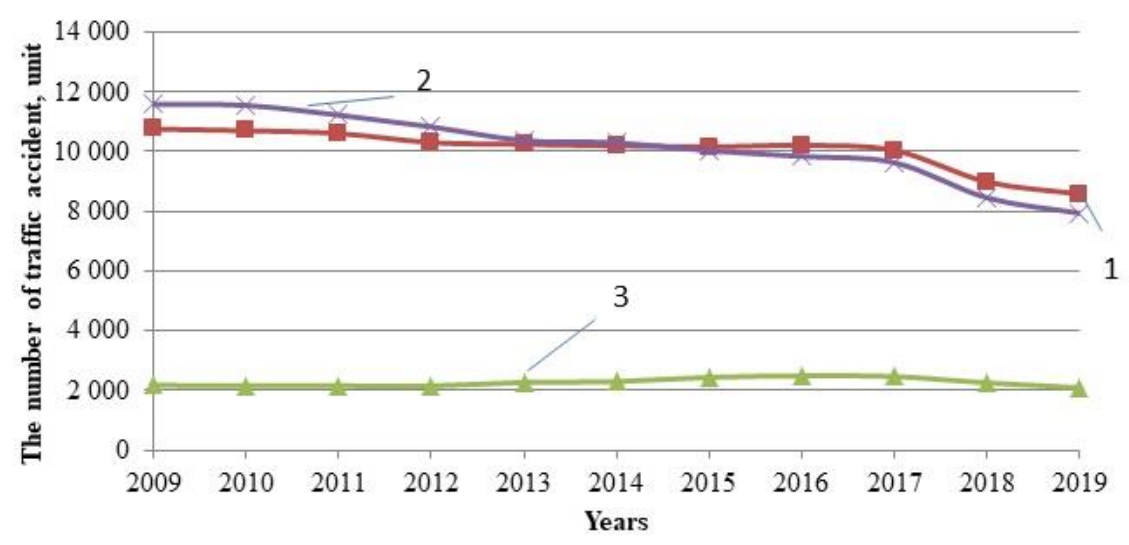

Figure 1. Statistics for traffic accidents in the Republic of Uzbekistan for the period 2009-2011 


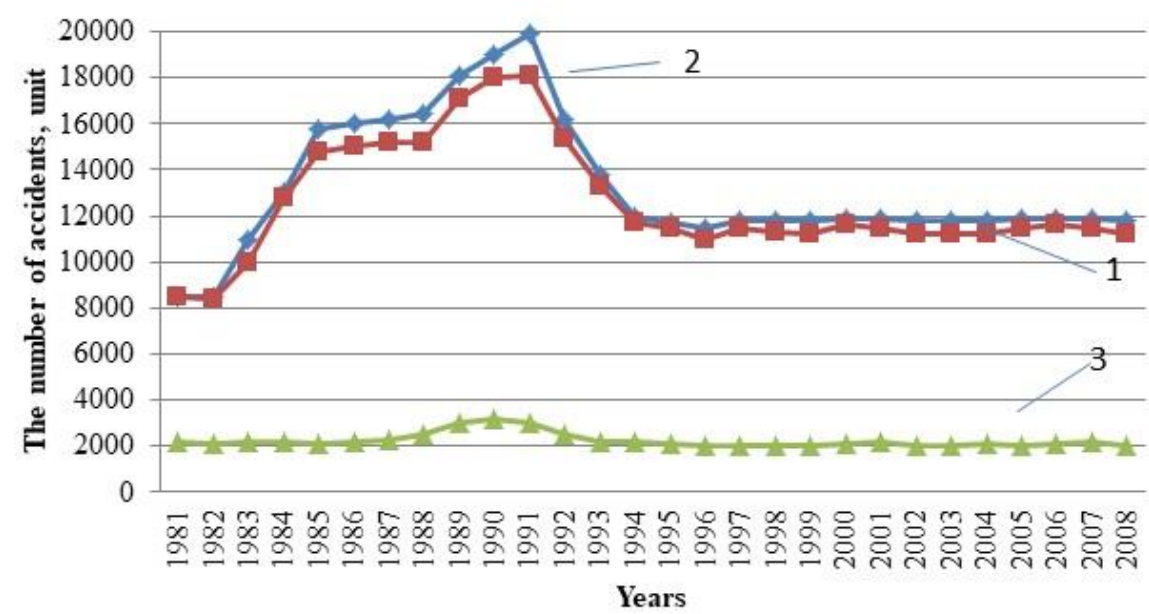

Figure 2. Information about traffic accidents on roads in the Republic of Uzbekistan for the period $1980 \div 2010$ [23, 24]: 1 - the total number of accidents; 2 - the number of victims in accidents; 3 - the number of deaths in traffic accidents

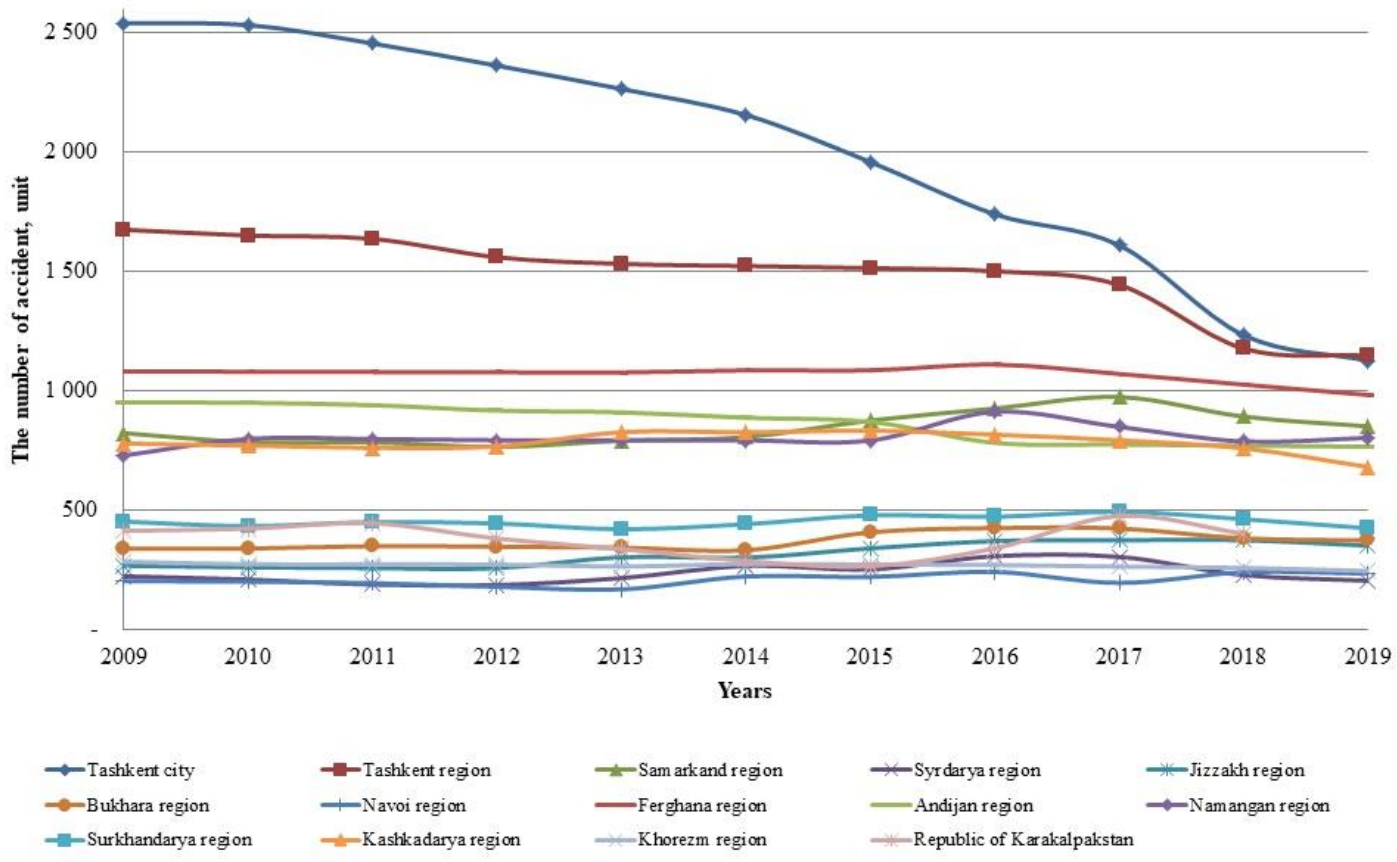

Figure 3. The number of traffic accidents in the regions of Uzbekistan

Table 1. Statistical data on types of accidents in the Republic of Uzbekistan

\begin{tabular}{cccccccccc}
\hline Years & \multicolumn{3}{c}{ Collision } & \multicolumn{3}{c}{ Rollover } & \multicolumn{2}{c}{ Hit a standing vehicle } \\
\cline { 2 - 10 } & $\begin{array}{c}\text { Total traffic } \\
\text { accidents }\end{array}$ & Died & Injured & $\begin{array}{c}\text { Total traffic } \\
\text { accidents }\end{array}$ & Died & Injured & $\begin{array}{c}\text { Total traffic } \\
\text { accidents }\end{array}$ & Died & Injured \\
\hline 2019 & 2373 & 616 & 2662 & 408 & 138 & 407 & 133 & 40 & 134 \\
2018 & 2354 & 664 & 2797 & 423 & 183 & 404 & 117 & 35 & 115 \\
2017 & 2228 & 616 & 2483 & 494 & 198 & 483 & 109 & 29 & 108 \\
2016 & 2242 & 642 & 2500 & 504 & 212 & 478 & 120 & 31 & 129 \\
2015 & 4232 & 1124 & 4752 & 833 & 314 & 817 & 184 & 61 & 178 \\
2014 & 4206 & 1193 & 4892 & 808 & 357 & 795 & 179 & 53 & 171 \\
\hline
\end{tabular}

\begin{tabular}{cccccccccc}
\hline Years & \multicolumn{2}{c}{ Hit an obstacle } & \multicolumn{2}{c}{ Hit a pedestrian } & \multicolumn{3}{c}{ Hit a cyclist } \\
\cline { 2 - 10 } & $\begin{array}{c}\text { Total traffic } \\
\text { accidents }\end{array}$ & Died & Injured & $\begin{array}{c}\text { Total traffic } \\
\text { accidents }\end{array}$ & Died & Injured & $\begin{array}{c}\text { Total traffic } \\
\text { accidents }\end{array}$ & Died & Injured \\
\hline 2019 & 440 & 146 & 452 & 4305 & 929 & 3530 & 729 & 191 & 563 \\
2018 & 423 & 149 & 442 & 4852 & 1035 & 4042 & 682 & 176 & 531 \\
2017 & 359 & 134 & 339 & 4096 & 824 & 3417 & 1044 & 236 & 850 \\
2016 & 380 & 113 & 374 & 4207 & 877 & 3509 & 979 & 248 & 777 \\
2015 & 759 & 246 & 749 & 7815 & 1723 & 6336 & 1472 & 384 & 1128 \\
2014 & 761 & 269 & 775 & 8453 & 1810 & 6959 & 1417 & 353 & 1121 \\
\hline
\end{tabular}




\begin{tabular}{cccccccc}
\hline Years & \multicolumn{2}{c}{ Hit a horse-drawn transport } & \multicolumn{3}{c}{ Hitting an animal } & Anot \\
\cline { 2 - 6 } & $\begin{array}{c}\text { Total traffic } \\
\text { accidents }\end{array}$ & Died & Injured & $\begin{array}{c}\text { Total traffic } \\
\text { accidents }\end{array}$ & Died & Injured & Another type of traffic accident \\
\hline 2019 & 36 & 5 & 34 & 8 & 4 & 6 & 85 \\
2018 & 40 & 5 & 40 & 4 & 1 & 4 & 95 \\
2017 & 27 & 4 & 26 & 7 & 4 & 5 & 86 \\
2016 & 34 & 4 & 37 & 3 & 0 & 3 & 87 \\
2015 & 72 & 11 & 70 & 16 & 8 & 12 & 153 \\
2014 & 75 & 13 & 70 & 6 & 1 & 7 & 158 \\
\hline
\end{tabular}

A detailed analysis of the types of accidents showed that over the past 6 years, the highest percentage is for pedestrian collisions, followed by vehicle collisions and then by collisions with cyclists. The figure shows that in 2019, 929 people were killed in accidents involving a pedestrian; 616 people in accidents involving vehicle collisions; and 191 people in accidents involving a cyclist (Table 1). Table 2 shows the approximate share of traffic violations by type.

In the Republic of Uzbekistan in recent years, traffic violations have sharply increased (Figure 4). This can be explained by the use of photo and video recording systems, which increased ability to identify violations of the rules of the road and to determine the violator. In 2019, there were $4,881,457$ traffic violations, while those violations revealed by the computerized control system amounted to $1,227,844$, representing a $25 \%$ increase in cited traffic violations (Table 3 and Figure 5).

Table 2. Percentage of traffic violations by type [29]

\begin{tabular}{cc}
\hline Type of traffic violation & $\mathbf{\%}$ \\
\hline Crossroads Violation & 15.8 \\
Driving technically faulty vehicle & 15.6 \\
Failure to overtake & 12.0 \\
Failure to comply with traffic signs & 7.5 \\
Over speed limit & 7.2 \\
Violation of the rules for parking, stopping or starting & 6.5 \\
Driving on the left side of the road & 3.5 \\
Use of cars for personal gain & 2.5 \\
Driving while intoxicated & 2.0 \\
Violation of the rules for using lighting devices & 1.6 \\
Violation of passenger transportation rules & 1.1 \\
Violation of the rules for passage of railway crossings & 0.6 \\
Blinding headlights despite an oncoming car & 0.5 \\
Violation of cargo transportation rules & 0.4 \\
Violation of the rules for towing vehicles & 0.2 \\
Other traffic violations & 23 \\
Total & 100 \\
\hline
\end{tabular}

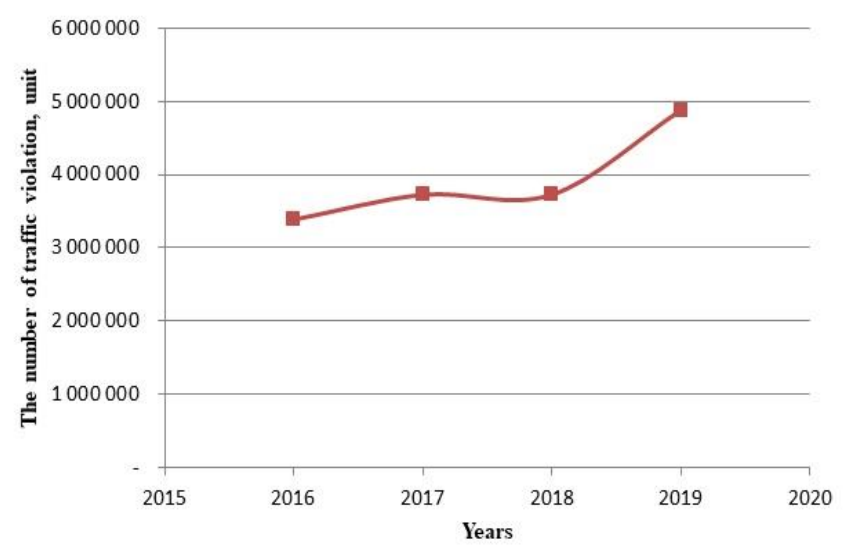

Figure 4. Traffic violation statistics

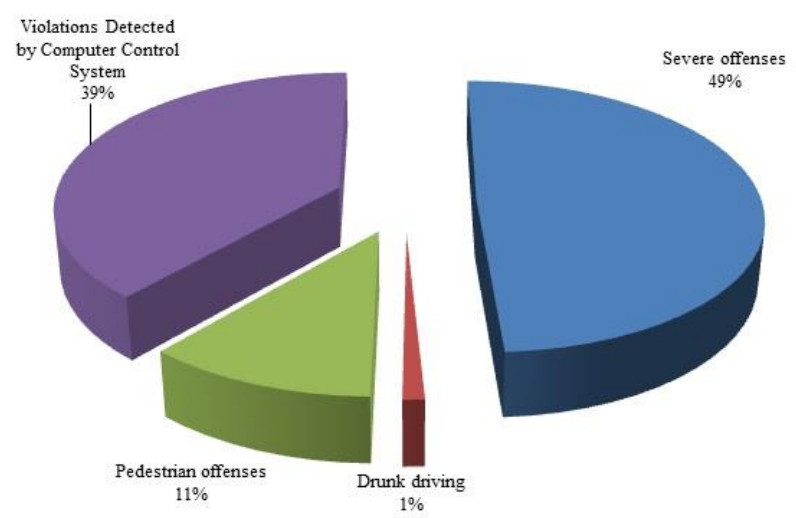

Figure 5. Statistics on traffic violations identified, 2019

Table 3. The share of traffic violations by causes in the Republic of Uzbekistan, 2019

\begin{tabular}{|c|c|c|}
\hline Reason for traffic violation & Quantity, pcs. & $\%$ \\
\hline $\begin{array}{l}\text { Failure to comply with road signs } \\
\text { and road markings }\end{array}$ & 2383182 & 48.82 \\
\hline Not using seat belts & 1526803 & 31.28 \\
\hline Traffic violations by pedestrians & 354658 & 7.27 \\
\hline Lack of documents & 198018 & 4.06 \\
\hline $\begin{array}{l}\text { Failure to comply with the speed } \\
\text { limit }\end{array}$ & 136334 & 2.79 \\
\hline $\begin{array}{c}\text { Parking in the wrong place ( } 3.27 \\
\text { sign) }\end{array}$ & 63327 & 1.30 \\
\hline Ignoring traffic signals & 61989 & 1.27 \\
\hline Lack of insurance & 55426 & 1.14 \\
\hline Drunk driving & 28098 & 0.58 \\
\hline Using a cell phone while driving & 25037 & 0.51 \\
\hline $\begin{array}{c}\text { Installation of sound and lighting } \\
\text { equipment }\end{array}$ & 9911 & 0.20 \\
\hline Window tinting & 9219 & 0.19 \\
\hline $\begin{array}{l}\text { Non-compliance with the } \\
\text { requirements of the traffic police }\end{array}$ & 7217 & 0.15 \\
\hline Refusal to take a blood alcohol test & 5595 & 0.11 \\
\hline $\begin{array}{c}\text { Oncoming traffic, creating a state of } \\
\text { emergency }\end{array}$ & 4530 & 0.09 \\
\hline Railroad crossing violation & 4344 & 0.09 \\
\hline Use of defective vehicles & 2390 & 0.05 \\
\hline $\begin{array}{c}\text { Violation of cargo transportation } \\
\text { rules }\end{array}$ & 1330 & 0.03 \\
\hline $\begin{array}{c}\text { Freight and passenger transportation } \\
\text { without a license }\end{array}$ & 1082 & 0.02 \\
\hline Group movement & 1031 & 0.02 \\
\hline $\begin{array}{l}\text { Monitor (display) installation in the } \\
\text { vehicle }\end{array}$ & 846 & 0.02 \\
\hline Damage to traffic control equipment & 741 & 0.02 \\
\hline Permission to drive drunk drivers & 263 & 0.01 \\
\hline Using a car for personal gain & 86 & 0.002 \\
\hline Total & 4881457 & 100 \\
\hline
\end{tabular}

When comparing traffic violations (1970 and 2019), there is a large difference in types. Of course, there are a number of 
"modern" violations of traffic rules that did not exist in 1970 and thus cannot be compared like using a cell phone while driving, installing a monitor (display), lack of insurance and not using seat belts. However, there are also standard violations of traffic rules, and the influence of traffic police efforts to ensure road safety can be observed. Table 4 presents a comparison of the number of traffic rules and the number of violations for ten violation types. Currently, an acute question persists regarding the "Failure to comply with road signs and road markings" by drivers and pedestrians, where the number reaches $48.8 \%$ and $7.7 \%$, respectively.

The registered number of violations of traffic rules due to excess speed represents $7.2 \%$ of the total number of detected violations, and the largest number of accidents is due to speeding $-48 \%$. A similar comparison can be made for types of violations such as driving on the left-hand side of the road when overtaking (3.5 and 17\%, respectively) and violations of the rules for crossing intersections (15.8 and 23\%). This situation can be explained by insufficient control over the streets and roads to ensure that drivers observe traffic rules. Although similar statistics can be seen for the Republic of Uzbekistan, they are not available in publicly available

resources.

An assessment of the correlation and regression relationships between the number of traffic violations and traffic accidents is shown in Figure 6-13 and Table 5-7.

Table 4. Comparative traffic violation data

\begin{tabular}{|c|c|c|c|}
\hline № & Types of traffic violations & $1970 \mathrm{y}$. & 2019 y. \\
\hline 1 & $\begin{array}{l}\text { Failure to comply with the speed } \\
\text { limit }\end{array}$ & 7.2 & 2.79 \\
\hline 2 & Parking in the wrong place & 6.5 & 1.30 \\
\hline 3 & Ignoring traffic signals & 15.8 & 1.27 \\
\hline 4 & $\begin{array}{c}\text { Oncoming traffic, creating a state of } \\
\text { emergency }\end{array}$ & 12 & 0.09 \\
\hline 5 & Railroad crossing violation & 15.8 & 0.09 \\
\hline 6 & Use of defective vehicles & 15.6 & 0.05 \\
\hline 7 & $\begin{array}{c}\text { Violation of cargo transportation } \\
\text { rules }\end{array}$ & 0.4 & 0.03 \\
\hline 8 & $\begin{array}{c}\text { Freight and passenger transportation } \\
\text { without a licence }\end{array}$ & 1.1 & 0.02 \\
\hline 9 & Using a car for personal gain & 2.5 & 0.002 \\
\hline 10 & Drunk driving & 2 & 0.61 \\
\hline
\end{tabular}

Table 5. Correlation between the number of traffic violations and traffic accidents (by region)

\begin{tabular}{|c|c|c|c|c|c|}
\hline $\begin{array}{c}\text { Variable } \\
\text { № } 1 \\
\end{array}$ & $\begin{array}{c}\text { Variable } \\
\text { №2 }\end{array}$ & $\begin{array}{c}\text { Linear correlation function } \\
\text { between variable } 1 \text { and variable } 2\end{array}$ & $\begin{array}{c}\text { Correlation } \\
\text { coefficient }\end{array}$ & F test & t test \\
\hline \multirow{4}{*}{$\begin{array}{l}\text { Number of } \\
\text { traffic } \\
\text { violations }\end{array}$} & The number of traffic accidents & $\mathrm{y}=342.6 \mathrm{x}+48238$ & $\mathrm{R}^{2}=0.478$ & $\mathrm{~F}=50.4$ & $\mathrm{t}=1.20$ \\
\hline & The number of fatalities from traffic accident & $y=661.7 x+16836$ & $\mathrm{R}^{2}=0.085$ & $\mathrm{~F}=5.11$ & $\mathrm{t}=3.09$ \\
\hline & The number of injured from traffic accidents & $y=359.5 x+49477$ & $\mathrm{R}^{2}=0.632$ & $\mathrm{~F}=94.1$ & $t=1.74$ \\
\hline & The number of accidents with economic damage & $y=-5377.4 x+433679$ & $\mathrm{R}^{2}=0.2083$ & $\mathrm{~F}=13.7$ & $\mathrm{t}=1.15$ \\
\hline
\end{tabular}

Table 6. Comparison of traffic violations and traffic accidents (by republic)

\begin{tabular}{cccccc}
\hline Years & Traffic violations & Traffic accident & Dead & Injured & Damage to property $^{\mathbf{1}}$ \\
\hline 2016 & 3385051 & 10212 & 2496 & 9845 & 8885 \\
2017 & 3725616 & 10044 & 2473 & 9637 & 9619 \\
2018 & 4347824 & 8990 & 2262 & 8458 & 10951 \\
2019 & 6109301 & 8588 & 2096 & 7943 & 12598 \\
\hline
\end{tabular}

${ }^{1}$ Sources: Traffic police of the Republic of Uzbekistan and *Fund for guaranteeing payments on compulsory civil liability insurance of vehicle owners.

Table 7. Correlation between the number of traffic violations and road accidents (by republic)

\begin{tabular}{cccccc}
\hline $\begin{array}{c}\text { Variable } \\
\text { No 1 }\end{array}$ & $\begin{array}{c}\text { Variable } \\
\text { No2 }\end{array}$ & $\begin{array}{c}\text { Linear correlation function } \\
\text { between variable 1 and variable 2 }\end{array}$ & $\begin{array}{c}\text { Correlation } \\
\text { coefficient }\end{array}$ & $\begin{array}{c}\text { F test } \\
\text { t test }\end{array}$ \\
\hline \multirow{2}{*}{$\begin{array}{c}\text { Number of } \\
\text { traffic }\end{array}$} & The number of traffic accidents & $\mathrm{y}=-1389 \mathrm{x}+2 \mathrm{E}+07$ & $\mathrm{R}^{2}=0.826$ & $\mathrm{~F}=9.53$ & $\mathrm{t}=4.1$ \\
violations & The number of fatalities from traffic accident & $\mathrm{y}=-6158 \mathrm{x}+2 \mathrm{E}+07$ & $\mathrm{R}^{2}=0.923$ & $\mathrm{~F}=24.2$ & $\mathrm{t}=6.4$ \\
& The number of injured from traffic accidents & $\mathrm{y}=-1213 \mathrm{x}+2 \mathrm{E}+07$ & $\mathrm{R}^{2}=0.843$ & $\mathrm{~F}=10.8$ & $\mathrm{t}=4.5$ \\
& The number of accidents with economic damage & $\mathrm{y}=725.5 \mathrm{x}-3 \mathrm{E}+06$ & $\mathrm{R}^{2}=0.953$ & $\mathrm{~F}=41.3$ & $\mathrm{t}=-2.7$ \\
\hline
\end{tabular}

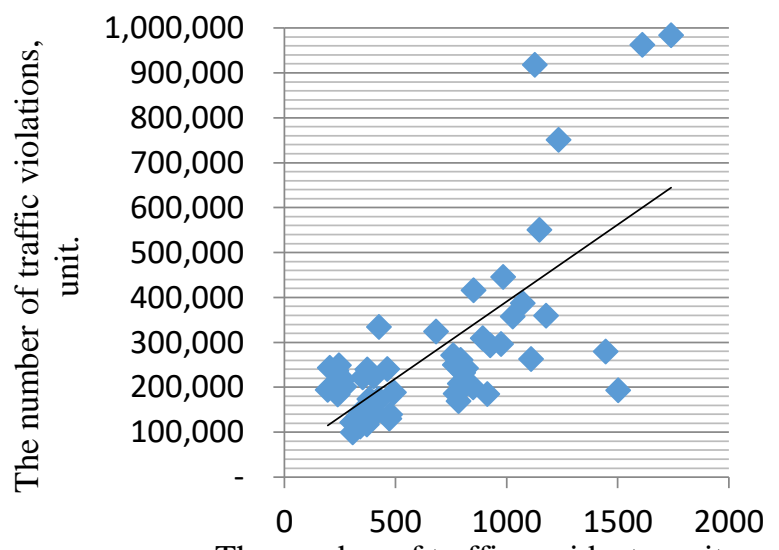

The number of traffic accidents, unit

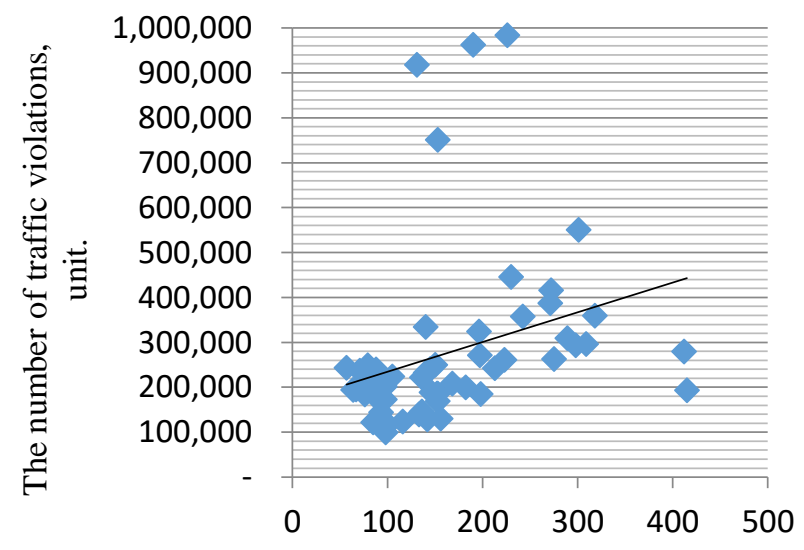

The number of deaths, unit
Figure 6. The relationship between traffic violations and traffic accidents
Figure 7. The relationship between traffic violations and deaths from traffic accidents 


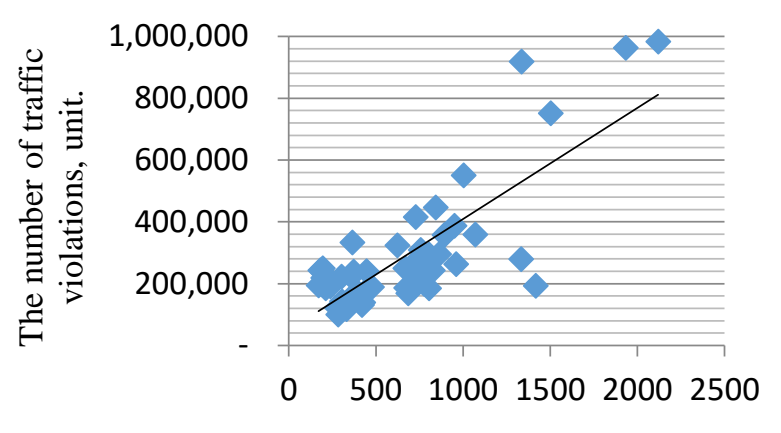

The number of injured, unit

Figure 8. The relationship between traffic violations and injured from traffic accidents

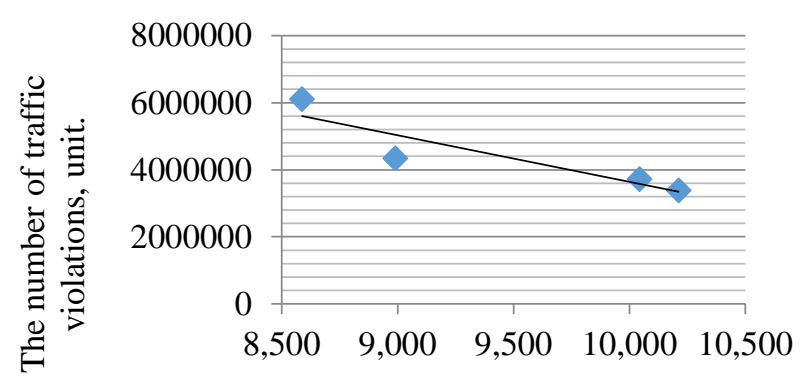

The number of traffic accidents, unit

Figure 10. The relationship between traffic violations and traffic accidents

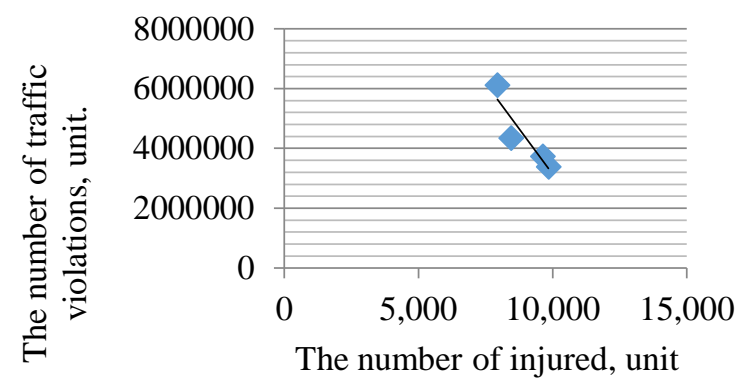

Figure 12. The relationship between traffic violations and injured from traffic accidents

\section{DISCUSSIONS}

By analysing data on the number of traffic violations and the number of traffic accidents, we concluded that during the analysed period, the number of traffic violations increased and the number of traffic accidents decreased.

In 2019, the number of traffic violations increased by $80.5 \%$ compared with 2016, while over the same period, the number of traffic accidents decreased by $19 \%$. Many researchers studying other countries [29-31] have investigated similar trends but have drawn exactly the opposite conclusions.

Other researchers have shown that there is a connection between traffic violations and traffic accidents, which means that a decrease in the number of traffic violations will lead to a decrease in the number of traffic accidents. They then conclude that eliminating the most frequent traffic violations could lead to a significant reduction in the number of traffic accidents and their consequences.

Additionally, other studies have shown that the number of

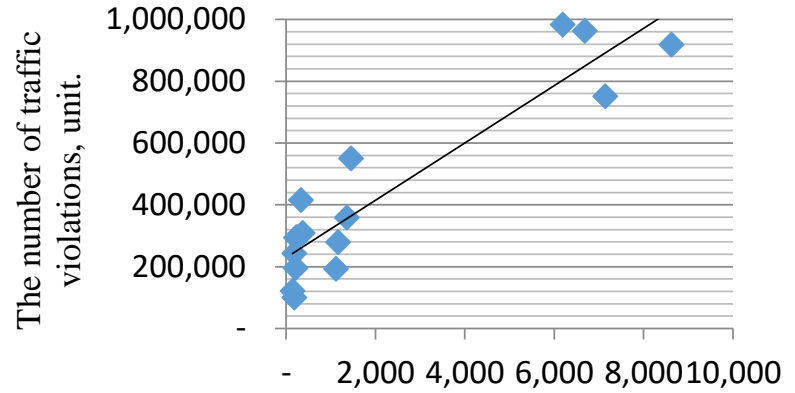

Traffic accident with economic damage, unit

Figure 9. The relationship between traffic violations and traffic accidents with economic damage

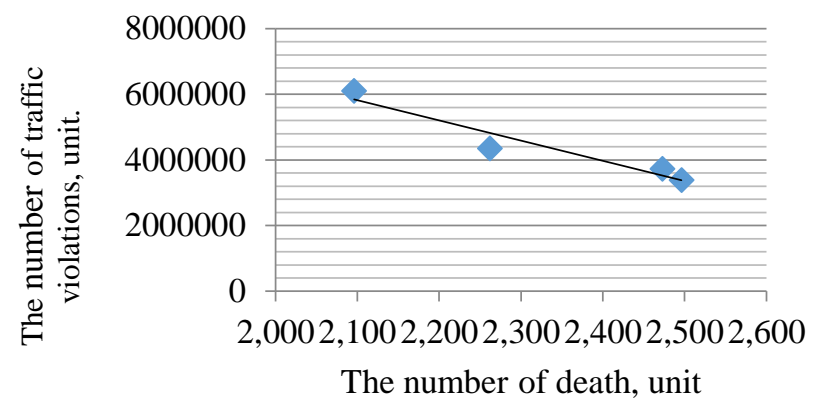

Figure 11. The relationship between traffic violations and deaths from traffic accidents

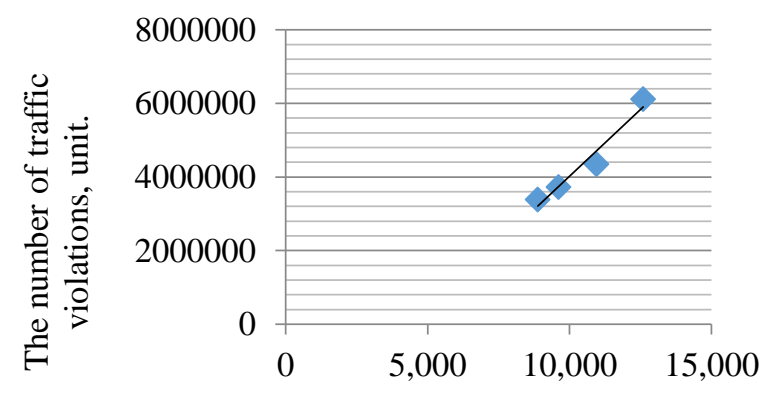

Traffic accident with economic damage, unit

Figure 13. The relationship between traffic violations and traffic accidents with economic damage

fatal accidents and other consequences is correlated with the number of registered or detected violations of traffic rules.

\section{CONCLUSIONS}

To determine the degree of correlation between the number of violations of traffic rules and the number of road traffic accidents and their consequences, we used the coefficient of determination $\left(\mathrm{R}^{2}\right)$. To determine whether the correlation was positive or negative, a correlation coefficient $(\mathrm{R})$ was used.

The analysis revealed the following:

(1). The number of violations of traffic rules is negatively correlated with the number and consequences of traffic accidents;

(2). The number of traffic violations has a strong negative correlation with the number of road traffic accidents and with the number of road traffic accidents with only material damage; 
(3). There is a negative correlation of average strength between the number of traffic violations and the number of road traffic accidents with victims;

(4). There is a weak negative correlation between the number of traffic violations and the number of fatalities in traffic accidents;

(5). Since the coefficient of determination does not exceed 0.9 , the so-called "single factor" does not exist.

The number of traffic violations is not the only factor affecting the number and consequences of traffic accidents. A relationship was found between the number of traffic rule violations detected and the consequences of accidents.

Thus, planning and development, which should provide the methodological foundations for ensuring traffic safety when designing street-road networks, is one of the most important measures that can reduce the number of violations and, consequently, improve road safety in Uzbekistan. These types of changes will incur financial costs but will save lives and provide other benefits such as increasing the speed and efficiency of road transport.

The authors recommend that the responsible authorities modernize the registration procedure, in particular switching to the electronic registration of accidents, and the analysis of their statistics.

\section{ACKNOWLEDGMENT}

This work was supported by the Project IZ-2020022810 Development of "Safe Road" software, funded by the Ministry of innovative development of the Republic of Uzbekistan.

\section{REFERENCES}

[1] World Health Organization. (2018). Global status report on road safety 2018: Summary (No WHO/NMH/NVI/18.20). World Health Organization.

[2] Abdunazarov Nurmuhumatovich, J., Mikusova, M. (2018). Application of GIS in automobile-road sector (Using the ArcGIS example). 8th International Scientific Conference CMD TOUR 2018, Slovakia, pp. 324-327.

[3] Abdunazarov, J.N. (2015). Justification the parameters of design vehicles for the design geometric elements of highways. PhD's thesis, Moscow, MADI, 143.

[4] Mikusova, M., Abdunazarov, J., Zukowska, J., Usmankulov, A. (2020). Designing of parking spaces taking into account the parameters of design vehicles in Russia. Communications-Scientific Letters of the University of Zilina, 22(2): 31-41. http://dx.doi.org/10.26552/com.C.2020.2.31-41

[5] Mikusova, M., Abdunazarov, J., Zukowska, J. (2019). Modelling of the movement of designed vehicles on parking space for designing parking. In International Conference on Transport Systems Telematics, Springer, Cham, pp. 188-201. http://dx.doi.org/10.1007/978-3030-27547-1_15

[6] Mikusova, M., Abdunazarov, J., Zukowska, J., Jagelcak, J. (2020). Designing of parking spaces on parking taking into account the parameters of design vehicles. Computation, $8(3)$ : https://doi.org/10.3390/computation8030071

[7] Sadikov, J. (2019). Improving the theoretical basis for forecasting and managing a system of road assets. DSc's thesis, Tashkent, Tashkent Institute for the Design, Construction and Operation of Roads, 197.

[8] Mikusova, M., Zukowska, J., Abdunazarov, J. (2019). Results of public opinion survey on distracted driving behaviour and attitudes. Archives of Transport System Telematics, 12.

[9] Abnunazarov, J., Mikusova, M. (2019). Testing trajectory of road trains with program complexes. The Archives of Automotive Engineering-Archiwum Motoryzacji, 83(1): 103-111.

[10] Zhang, G., Yau, K.K., Chen, G. (2013). Risk factors associated with traffic violations and accident severity in China. Accident Analysis \& Prevention, 59: 18-25. http://dx.doi.org/10.1016/j.aap.2013.05.004

[11] Zhang, G., Yau, K.K., Gong, X. (2014). Traffic violations in Guangdong Province of China: Speeding and drunk driving. Accident Analysis \& Prevention, 64: 30-40. http://dx.doi.org/10.1016/j.aap.2013.11.002

[12] Harrington, D.M., McBride, R.S. (1970). Traffic violations by type, age, sex, and marital status. Accident Analysis \& Prevention, 2(1): 67-79. http://dx.doi.org/10.1016/0001-4575(70)90008-4

[13] Pesic, D., Vujanic, M., Lipovac, K., Antic, B. (2011). Analysis of possibility for traffic safety improvement based on Serbian traffic violation database analysis. Scientific Research and Essays, 6(29): 6140-6151. https://doi.org/10.5897/SRE11.1272

[14] Rimmö, P.A., Ảberg, L. (1999). On the distinction between violations and errors: Sensation seeking associations. Transportation Research Part F: Traffic Psychology and Behaviour, 2(3): 151-166. https://doi.org/10.1016/S1369-8478(99)00013-3

[15] Azemsha, S.A., Galushko, V.N., Skirkovsky, S.V., Vrubel, Yu.A. (2015). Analysis of data on road traffic accidents and their causes for the city of Gomel in 2013 and 2014 Science and technology. (In Russian) Science and Technology, (3): 65-73.

[16] Ayuso, M., Guillén, M., Alcañiz, M. (2010). The impact of traffic violations on the estimated cost of traffic accidents with victims. Accident Analysis \& Prevention, 42(2): 709-717. http://dx.doi.org/10.1016/j.aap.2009.10.020

[17] Yusupov, Y. (2010). Multivariate analysis of traffic violations by drivers of vehicles in the Gissar region of Tajikistan. (In Russian). News of the Academy of Sciences of the Republic of Tajikistan. Department of Physical, Mathematical, Chemical, Geological and Technical Sciences, (2): 100-106.

[18] Ilyina, I.E., Lyandenbursky, V.V., Pylaykin, S.A. Evstratova, S.A. (2013). Analysis of accidents and causes of violation by drivers of traffic rules in the Penza region. (In Russian). Internet Journal of Science, (1): 6868

[19] Elliott, M.A., Baughan, C.J., Sexton, B.F. (2007). Errors and violations in relation to motorcyclists' crash risk. Accident Analysis \& Prevention, 39(3): 491-499. http://dx.doi.org/10.1016/j.aap.2006.08.012

[20] Mesken, J., Lajunen, T., Summala, H. (2002). Interpersonal violations, speeding violations and their relation to accident involvement in Finland. Ergonomics, 45(7): 469-483. http://dx.doi.org/10.1080/00140130210129682

[21] Parker, D., Reason, J.T., Manstead, A.S., Stradling, S.G. (1995). Driving errors, driving violations and accident 
involvement. Ergonomics, 38(5): 1036-1048. http://dx.doi.org/10.1080/00140139508925170

[22] Liu, Z., Wu, H., Li, R. (2020). Effects of the penalty mechanism against traffic violations in China: A joint frailty model of recurrent violations and a terminal accident. Accident Analysis \& Prevention, 141: 105547. https://doi.org/10.1016/j.aap.2020.105547

[23] Azizov, K. (2002) Basics of Traffic Safety. Tashkent: Teacher. p. 210.

[24] Azizov, K. (2012) Basics of Traffic Safety. 2nd ed. Tashkent: Science and Technology. p. 293.

[25] Li, Y., Abdel-Aty, M., Yuan, J., Cheng, Z., Lu, J. (2020). Analyzing traffic violation behavior at urban intersections: A spatio-temporal kernel density estimation approach using automated enforcement system data. Accident Analysis \& Prevention, 141: 105509. https://doi.org/10.1016/j.aap.2020.105509

[26] Martínez-Ruíz, D.M., Fandiño-Losada, A., de Leon, A.P., Arango-Londoño, D., Mateus, J.C., Jaramillo-Molina, C., Bonilla-Escobar, F.J., Vivas, H., Vanlaar, W., GutiérrezMartínez, M.I. (2019). Impact evaluation of camera enforcement for traffic violations in Cali, Colombia, 2008-2014. Accident Analysis \& Prevention, 125: 267-
274. https://doi.org/10.1016/j.aap.2019.02.002

[27] Cohn, E.G., Kakar, S., Perkins, C., Steinbach, R., Edwards, P. (2020). Red light camera interventions for reducing traffic violations and traffic crashes: A systematic review. Campbell Systematic Reviews, 16(2): e1091. https://doi.org/10.1002/cl2.1091

[28] Factor, R., Kaplan-Harel, G., Turgeman, R., Perry, S. (2020). Overcoming the benchmark problem in estimating bias in traffic enforcement: The use of automatic traffic enforcement cameras. Journal of Experimental Criminology, 1-21. https://doi.org/10.1007/s11292-020-09414-1

[29] Mogila, V.P., Davydov, L.N., Konek, Y.S. (1977). Prevention of road traffic accidents in motor vehicles. M .: Transport.

[30] Rajalin, S. (1994). The connection between risky driving and involvement in fatal accidents. Accident Analysis \& Prevention, 26(5): 555-562. http://dx.doi.org/10.1016/0001-4575(94)90017-5

[31] Elvik, R. (1997). Effects on accidents of automatic speed enforcement in Norway. Transportation Research Record, 1595(1): 14-19. http://dx.doi.org/10.3141/1595-03 